\title{
Colonial Coins of the Western Europe from the Funds of Khabarovsk Local Lore Museum Named after N.I. Grodekov (Semiotic Aspect)
}

\author{
Evgeniya V. Kolesnikova* \\ Khabarovsk Local Lore Museum named after N.I. Grodekov \\ 11 Shevchenko Str., Khabarovsk, 680000, Russia
}

Received 11.12.2016, received in revised form 16.02.2016, accepted 20.04.2016

The article deals with the history of colonial coins in the funds of the museum, studies authentic museum objects and interprets them from the point of view of the culture semiotics, while coins are the "witnesses of the past". The article is descriptive.

Keywords: colonial coins, value, head side, tail side, source, chop mark.

DOI: 10.17516/1997-1370-2016-9-6-1474-1479.

Research area: culture studies.

From the $15^{\text {th }}$ century, the countries of the Western Europe began to explore new lands conquering the population that inhabited it.

The desire for colonial acquisitions was due to several factors: trade development, release of the most of Europe from the Arab conquerors. One means of influence on the subordinate territories was the issue of coins regulated by the metropolis. Colonial coins were minted both in the metropolis and in the colony.

Colonial coins are the coins minted for circulation in the occupied territories. Often these coins were different from the coins of the metropolis and were not in circulation beyond such territories. The coins had existed since ancient times, such as the Roman provincial coins of Syria - tetradrachm of Seleucus [Abramzon, 1995].
The regional museum has quite an extensive collection of coins, with more than 13,000 items. Among them, there are about 300 colonial coins of Western Europe.

At the moment, it is quite difficult to determine where the numismatic collections of the funds have come from and to relate the source with a certain coin collection. It is known that most of the coins come from private collections, educational institutions, have been obtained in the course of archaeological excavations. The years of arrival, the names of the people who gave the coins and coin denominations are known. Thus, from N.I. Grodekov were received: coins of the colonies of 1890s (UK), coins of France of 1890 for Indochina; the member of the Division of the IRGS E.V. Lopatina donated a collection of coins (93 pcs.); K.E. Pfaffius presented a

\footnotetext{
(C) Siberian Federal University. All rights reserved

* Corresponding author E-mail address: eva.gene@mail.ru
} 
collection of 34 coins which were in use in the Kwantung Peninsula; Kushnarev donated 1 cent of the British colony (Strait Settlement) of 1890, 1 cent of Borneo; the coins of different European countries came from the former museum of Khabarovsk Cadet Corps to Grodekov's Museum in 1918 - coins of Austria, France, Germany. In 1896, Captain M.A. Sokovnin donated the coins of French Indochina; P. Shkurkin presented the museum with the ancient Phoenician coins, 12 copper Roman coins, 1 silver Austrian coin of 1890s for the trade on the east coast of Africa (minted in Trieste); Mitrofanov among others donated 20 cents of French colony in 1866, Shchadrin in 1902 gave a collection of coins with French colonial coins [Fondy].

Among the museum collection, the coins of French and British colonies can be outlined.

Let us consider several coins of different colonies of these countries in terms of semiotics, while the images on the coins can be an additional source of the history of these countries, their cultural peculiarities, influence of the European culture on the subordinate territories. The coin of the British colony Hong Kong of 1 cent (KhKM KP 5372/91) (Fig.1) minted by the Royal Mint in London in 1863 has the head-and-shoulders portrait of Queen Victoria with the crown in the center on the head side. On the right and on the left it is written "VICTORIA QUEEN". On the tail side: in the centre the Chinese characters are arranged crosswise repeating the text of the circular legend in English. Hieroglyphic symbols are surrounded by a circular dotted pattern. On the external part it is written "ONE CENT 1863 HONG-KONG". European protection of the conquered territory can be traced from the British monetary system - the nominal value of the coin is a cent, the portrait of the Queen of England on the head side is also remarkable, while the head of the coin always contains the most significant images. Another British colonial coin of 1 cent for the Ceylon colony (KhKM KP 5372/100) (Fig.2), minted by the Calcutta Mint in India contains the head-and-shoulders image of Queen Victoria in the centre of the head side. Along the external part, there is a pattern, meander, above and below the portrait it is written "VICTORIA QUEEN". On the tail side: in the centre there is the talipot palm, on the left there is an inscription on the Singhalese, on the right there is an inscription on the Tamil. The image is in the circle. Along the external part it is written "CEYLON ONE CENT 1870 ".

The combination of the Queen Victoria's portrait and meander framing the image on both sides is quite interesting. Meander is not only a decoration. The author of the article assumes that this pattern can be interpreted as the symbol of the English fleet influence in the sea. The palm tree on the tail side is interpreted as one of the symbols of India from the point of view of Europeans. For indigenous people, the palm tree is a symbol of longevity, the leaves of this species of palm trees were used in religious processions. It is interesting that the tree blooms once and then dies. The author of the article considers representation of this palm tree on the coin to be non-coincidental: as we know, the European domination in the colonies was primarily pumping out all the resources from the territory and going to a new land, so that the palm tree in this case represents a reminder of the sad fate of the Indian colonies. The coin of 1 cent of 1889 (KhKM KP 5372/106) (Fig.3) minted in Birmingham by Heaton Mint has the value written on the head side, "ONE CENT", framed by the laurel wreath. On the top and on the bottom of the value there are hieroglyphic symbols. On the external part, it is written: "BRITISH NORTH BORNEO Co". On the tail side, in the centre there is the coat of arms of the British joint-stock company, with indigenous people by its sides, in loincloths and with weapons in their hands. This is the coin of 

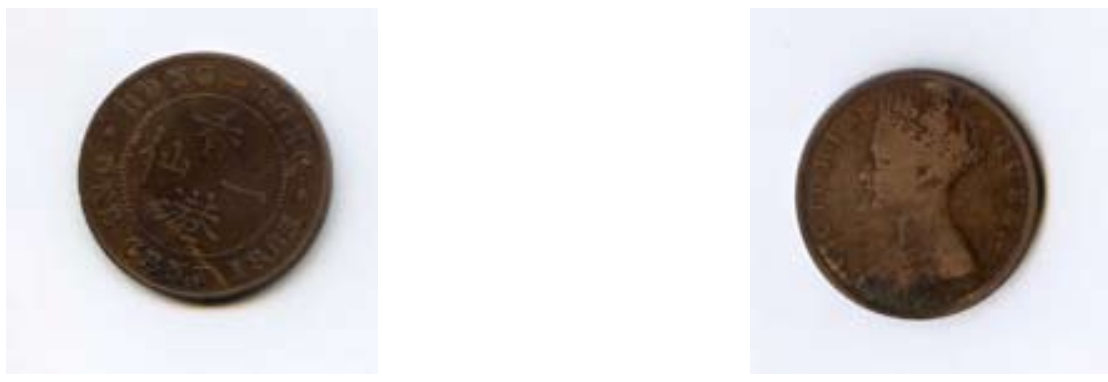

Fig. 1
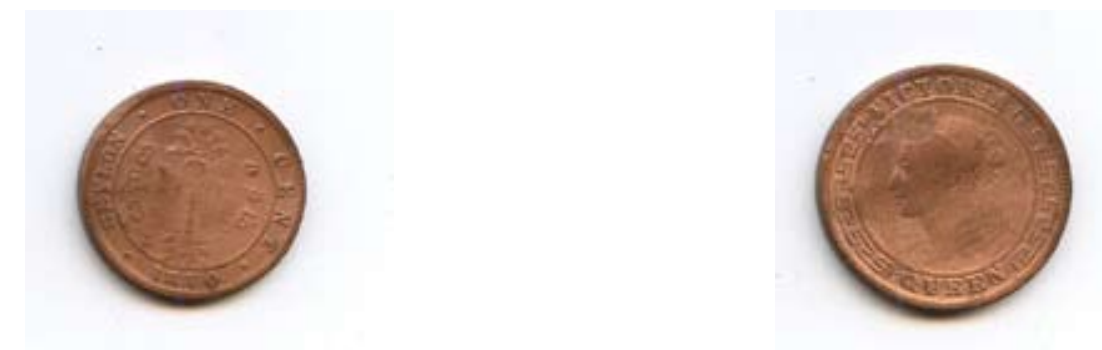

Fig. 2
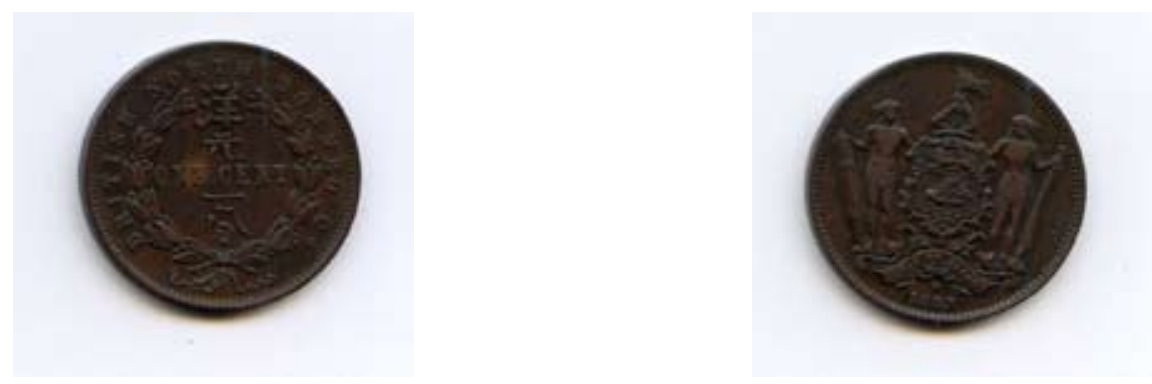

Fig. 3

the British colony in North Borneo. On the head side there is an image of a wreath: the symbol of victory (tradition since ancient times). Chinese and Arabic characters on the coin indicate trade relations with China and Arab territories.

The coin of the East India Company, an English joint-stock company organized to pursue trade in India, is also worth mentioning. The Company was one of the tools used for colonization of India. During the Company's ruinous policy the financial capital of the UK had reached great heights, but for India this policy had led to the destruction of many unique crafts, depletion of resources, including human resources: more than 30 millions of indigenous population were killed. The colonial coin of the Stock Company "East India Company", "1/4 annas" (KhKM KP 5372/110) (Fig. 4), was minted in India by the Mint in Madras Presidency in 1835. The head side: the coat of arms of the British East India Company cover the whole head: two lions holding the coat of arms, which depicts the third lion. Below there is the year " 1835 " and a stylized ribbon. There is a shortened legend in Latin under the date on the head side: "AUSP: REG: \& SEN: ANG", i.e. "AUSPICIO REGIS ET SENATUS ANGILIAE" (Under the auspices of the King and the British Parliament). The tail side of the coin has an inscription at the top: "EAST INDIA COMPANY". The inscription in Persian refers 


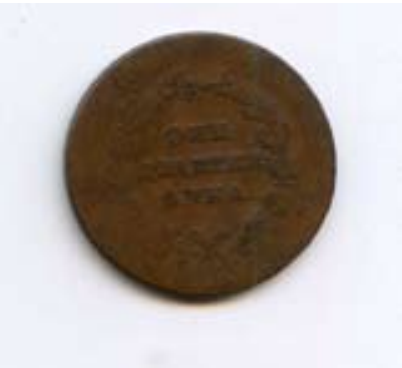

Fig. 4

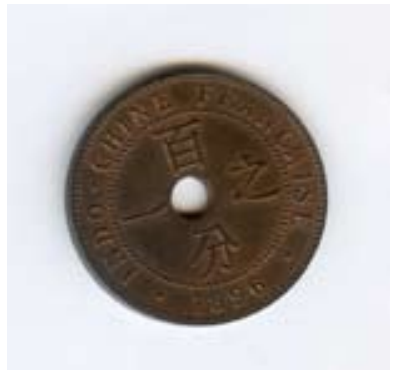

Fig. 5
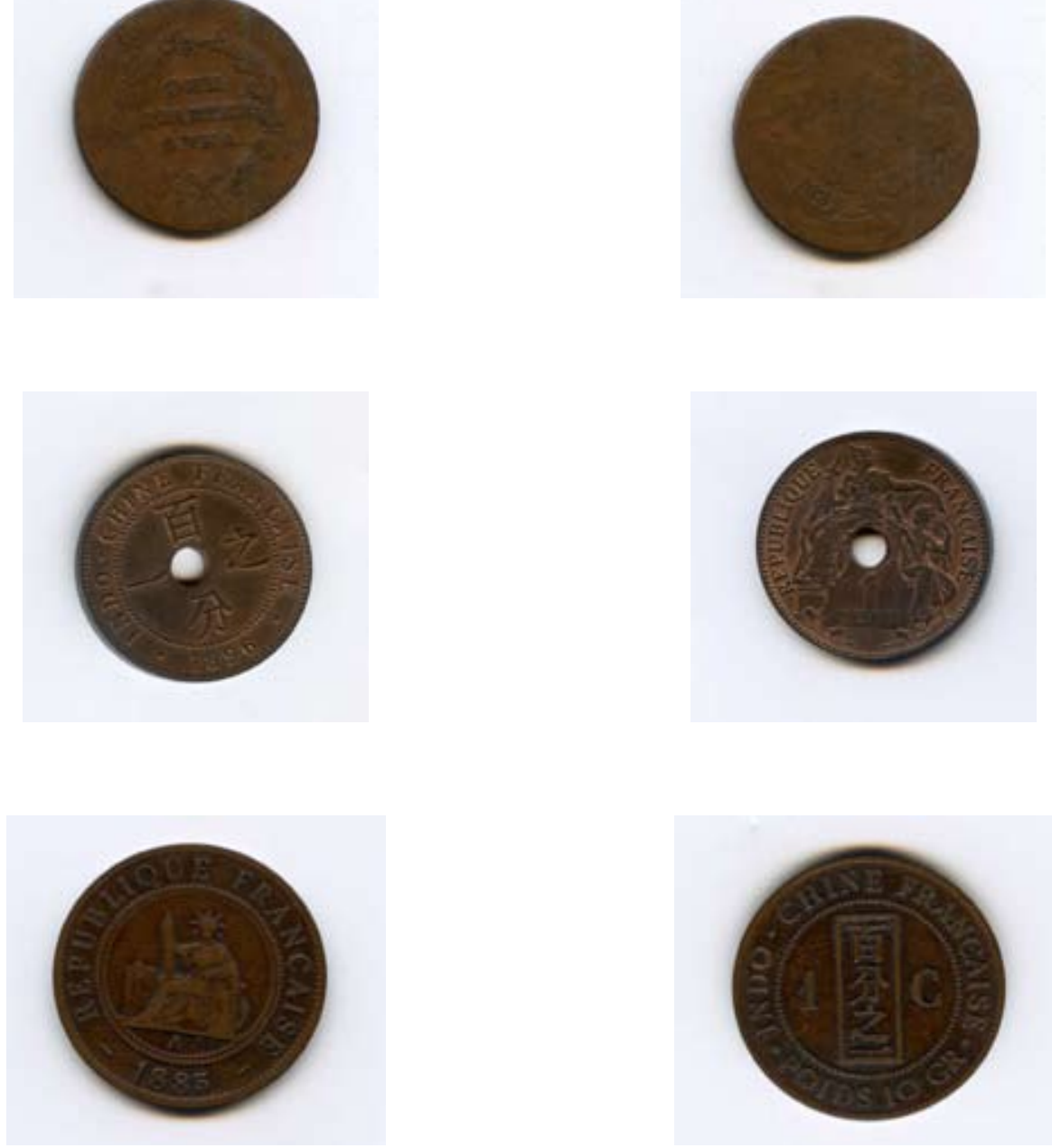

Fig. 6

to its value. The tail side: in the centre there is the value written in 3 lines: "ONE / QUARTER / ANNA" framed by the laurel wreath. On this coin the leading role is also given to the coat of arms of the company which conquered the territories and carried out trade on the territories under its control.

Now let us consider the coins of the French colonies. The coin of "1 cent" of 1896 of the French colony Indo-China (KhKM KP 5372/97) (Fig. 5) minted by the Paris Mint, the image of the Liberty sitting on the pedestal. On the right there is an image of a sitting woman. On the left and on the right there is an inscription "REPUBLIQUE FRANCAISE". At
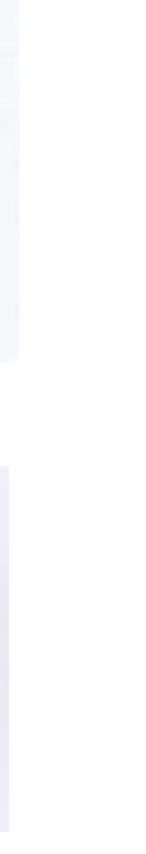
through hole typical for Chinese coins and Chinese hieroglyphic symbols on the tail side.

On the other coin of the French colony Indo-China "1 cent" (KhKM KP 5372/99) (Fig.6) minted in France by the Paris Mint in 1885 , there is an image of the sitting Liberty in the centre of the head side, in the draping material and a radiant crown holding Lictor's fascia. Below the cut there is a chop mark of the Mint: "A" and initials "A.B.". The image is framed by a circular dotted ornament. Along the external part, there is an inscription: REPUBLIQUE FRANCAISE 1885. On the tail side in the centre in the rectangular frame there are Chinese symbols, on the right and on the left of the frame there is the nominal value " 1 " and "C": One cent. The image is framed by a circular dotted ornament. Along the external part there is an inscription: INDO - CHINE FRANCAISE POIDS $10 \mathrm{GR}$.

In the centre of the coin there is one of the symbols of the French Republic: the personification of Liberty. The attributes that surround it - anchor, spikes, Lictor's fascia indicate the following: the anchor represents France, a maritime power, the spikes represent a strong economy, the Lictor's fascia represents the national unity.

It is no coincidence that coins are called the witnesses of the past. Being the means of payment, they have been reflecting historical realias. Colonial coins are an interesting source to study the culture and assimilation of different cultures.

\section{References}

Fondy Khabarovskogo kraevogo muzeia imeni N.I. Grodekova. KhKM KP 7872. (F. 1 Op. 102. D. 1.) [Funds of Khabarovsk Regional Museum named after N.I. Grodekov].

Abramzon, M.G. (1995). Monety kak sredstvo propagandy ofitsial'noi politiki Rimskoi Imperii [Coins as the means of propaganda of the official policy of the Roman Empire]. Moscow, Institut arkheologii Rossiiskoi Akademii nauk [Institute of Archeology of the Russian Academy of Sciences], $748 \mathrm{p}$.

Efimov, E.G. (2007). Angliiskaia Ost-Indskaia kompaniia vo vtoroi polovine XVIII veka: vopros o natsional'noi identichnosti ( $k$ postanovke problemy) [English East India Company in the second half of the $18^{\text {th }}$ century: the issue of national identity (on the statement of the problem)]. XI regional'naia konferentsiia molodykh issledovatelei Volgogradskoi oblasti [XI Regional Conference of Young Researchers of the Volgograd Oblast]. Filosofskie nauki i kul'turologiia. Istoricheskie nauki [Philosophy and Culture Studies. History]. 3, Volgograd, 124-126.

Entsiklopediia simvolov, znakov, emblem [Encyclopedia of Symbols, Signs and Emblems] (2005). Moscow, Eksmo; St. Petersberg, Midgrad, 608 p. 


\section{Колониальные монеты Западной Европы \\ из фондов Хабаровского краеведческого музея \\ имени Н.И. Гродекова (семиотический аспект)}

Е.В. Колесникова

Хабаровский краеведческий музей имени Н.И. Гродекова Россия, 680000, Хабаровск, ул. Шевченко, 11

В статье рассматриваются вопросы, связанные с историей появления колониальных монет в фондах музея, исследуются визуально подлинные музейные предметы и трактуются с точки зрения семиотики культуры, так как монеты выступают «свидетелями прошлого». Статья носит описательный характер.

Ключевые слова: колониальные монеты, номинал, аверс, реверс, источник поступления, клеймо.

Научная специальность: 24.00.00 - культурология. 